friend of Robert's, whereupon the priory was formally besieged by Robert, who insisted on the monks deposing the new prior from St. Alban's. On complaint being made to John of this violent action he swore 'per pedes Dei, ut moris habuit,' that either he or Robert should be king of England. For, we read, they bated one another, and the king rejoiced at the chance of avenging himself on Robert. A friend of the latter was able to send him warning just in time for bim to seok sefety in flight before the arrival of the king's troops. This took place ' in the time of the Interdict.'

It may be usefal, in conclusion, to correct a misepprehension as to Robert Fitzwalter's issue. Dugdale erroneously makes his son and successor Walter to be born of his marriage with Gunnora of Valognes. ${ }^{16}$ Professor Tout writes that

This Walter must have been either a younger son or a grandson. After the desth of Gunnor (she was alive in 1207) it is said that Fitzwalter married a second wife, Bohese, who survived him. ${ }^{17}$

It is now known that Walter, Robert's successor, was his son by his second wife, and that Christine, his danghter by the Valognes heiress, inherited her mether's barony..$^{18}$ The Histoire des Ducs ensbles us to add a son and another danghter by Gunnora de Valognes, of whom the son was captared with his father at the battle of Lincoln, while they both died without issue, as did evantually Christina also.

J. H. Round.

\title{
The Tactics of the Battles of Boroughbridge and Morlaix.
}

Is his important paper on the archers at Crecy in the English Historical Review, xii. 427-436, and also in his Welsh Wars of Edrcard I, Mr. J. E. Morris has thrown into clear relief the evolution of English tactics from Falkirk to Crecy. In his former article he 'appealed from Crecy to other battles' with very interesting results. But, as his chief object was to emphasise the gradual development of the employment of archery, he was naturally led to pay less attention to other aspects of the new tactics. I propose here to call attention to two links in the chain of development from Falkirk to Crecy which Mr. Morris has overlooked, doubtless as having in one case no great and in the other very little bearing on the particalar point of archery. These two links are the battle of Boroughbridge of 1322 and the battle near Morlaix of 1342. The former of these shows English soldiers first applying against their $\mathrm{n}$ wn countrymen the Scottish system of fighting; the second seems to be the first occasion on which the

\footnotetext{
1- Baronage, i. 220.1 "Dictionary of National Biagraphy, xix. 222.

1. See my article on 'Comyn and Valoignes' in the Arcestor, Oct. 1904.
} 
tactics which later secured victory at Crecy were employed by Englishmen in a pitched battle on the continent. Neither of these fights has any place in Professor Oman's History of the Art of War.

There is no need to tell from the chroniclers the story of either of these battles. At Boroughbridge Earls Thomas of Lancaster and Humphrey of Hereford were retreating with their partisans from Edward II's forces in the direction of Bcotland, when they were intercepted at the moment of their passage over the Ure by Sir Andrew Harclay and his border levies, well tried in the hard experience of warfare against Robert Bruce. On reaching the Ure Lancaster found the north bank of the stream, particularly the approaches to the bridge and the only neigbbouring ford, strongly held by Harclay's men. The so called 'Chronicle of Lanercost' best gives the disposition of his forces.

[Andreas de Harclsy] praevenit comitem et preoccupavit pontem de Burghbrigge, et dimissis retro equis suis et sworum statuit in pedibus omnes milites et quosdam lancearios ad borealem partem pontis, et contra vadum sive transitum aquae posuit alios lancearios in scheltrum secundusm modum Scotorum ad resistendum equitibus et equis in quibus adversarii confidebant. Sagittariis autem pracepit at venientibus inimicis spisse et continue eagittarent. ${ }^{1}$

Here we have (a) the dismounting of the knights and men-atarms, $(b)$ the conscious adaptation of the Scottish formation of the 'scheltrum' or square of pikemen, (c) the stress laid on the use of archers to ward off the enemies' attack, (d) the defensive tactics that these changes practically involved. Of course not all these things were complete novelties. I do not forget the knights who, as Professor Oman has shown us, fought on foot in earlier battles, as, for example, at Tenchebrai, at Bremûle, and at Lincoln (1141), but these earlier instances are outside the chain that binds Falkirk to Crecy. Limiting ourselves to this series, we cannot but see that Boroughbridge thus affords 'the earliest hint of the new English policy of dismounting,' and not the landing of the Disinherited on the coast of Fife just before Dupplin Moor, as Mr. Morris has taught us to believe. We must therefore qualify the suggestion of the canon of Bridlington, whom Mr. Morris quotes, to the effect that the dismounting policy before Dupplin was accidental, and was continued because found effective. We know from the Lanercost writer that it had been effective ten years earlier.

Harclay's disposition of his troops assured him an easy victory. It was in vain that the two earls set another precedent for the array of Dupplin, Halidon, and Crecy by deciding that Hereford and Clifford should dismount with their followers and proceed on foot to the attack on the bridge.

\footnotetext{
' Chron. de Larercost, pp. 348-4 (Bannatyne Club).
} 
Comites [sc. Lancaster and Hereford] . . videntes dominum Andream praeoccupasse borialem partem pontis, ordinaverunt quod comes Herefordiae et dominus Rogerns de Clifforde . . . cum comitiva sua procederent in pedibus et arriperent pontem supre lancesrios."

A glance taught Lancaster and Hereford, though neither was a great captain, what the French took years to learn-namely, that the dismounted pikemen could best be dealt with by opponents who accepted their method of fighting. It is curious, however, that Hereford with his Gwentian experience made no use of archers to clear away the defenders of the bridge, though the account of his failure and death shows that Harclay's archers had their part in his defeat.

Turning to Lancester's attempt to cross the ford on horseback, we find that it was equally unsuccessful. As the Lanercost writer goes on-

Equites autem comitis qui voluerunt aquam transivisse, non potuerunt eam intrare prae multitudine et spissitudine telorum quae a sagittariis mittebantar in eos et in equos eoram. ${ }^{3}$

From these details we may infer that Boroughbridge rather than Dupplin Moor is the real starting-point of the English adoption of the new tactics that $\mathrm{Mr}$. Morris has so well described. It is significant that the first English host to employ them should be Harclay's army of borderers, well tried in the conditions of Scottish warfare. Unluckily the Lanercost chronicler does not tell us where the archers of Harclay were posted. Assuming, if we may do so, that they were 'interlaced' with the foot, as in some of Edward I's Welsh battles, we may conclude that the chief improvement effected at Dupplin was the putting the archers in the wings.

The significance of the second battle, to which I wish to call attention, has been even more completely overlooked by modern writers, though there are fairly full recent accounts of it by Dr. Mackinnon ${ }^{4}$ and M. Arthar de la Borderie. ${ }^{5}$ The fight in question was fought by the earl of Northampton, near Morlaix, in Brittany, on 30 Sept. 1342 . Northampton had been sent by Edward III to help the Montfortians, while the king prepared a larger expedition. After many successes in Leon and Cornouailles, both Montfortian regions, Northampton rentured to attack the stronghold of Charles of Blois, the vast county of Penthièvre, and besieged Morlaix, its south-western bulwark. Driven by Charles of Blois from the siege, he was forced to retreat further away from his base at Brest towards Lanmear, on the road to Lannion. ${ }^{\circ}$ Between Morlaix and Lanmear he was forced to give battle. We seem in-

Chron. de Lanercost, p. 243.

- Hist. of Edward III, pp. 233-4. $\quad$ Hist. de Bretagre, iil. 466-7.

- This direction of the retreat comes from an anedited charter, quoted ibid. iii. 167. 
debted for our knowledge of this fight to English writers exclusively. Of these Murimuth ${ }^{7}$ simply emphasises in two detached passages the importance of the English victory and the immense numerical superiority of the defeated side, Northampton having 500 men against Charles of Blois's 52,000 men-8t-arms. But these random and ridicalons figures stand in confliot with a previous reference to what is plainly the same battle, in which Cherles's numbers are 3,000 armati and 1,500 Genoese. ${ }^{8}$ More valuable evidence comes from Knighton and Geofirey le Baker. Of these Knighton ${ }^{\circ}$ is by far the more precise as regards the disposition of the forces. After telling us that Charles of Blois cum $x x$ mille viris had raised the siege of quandam izllam cum castro-clearly of Morlaix-he goes on to describe the array :

Et mane ceperunt [sc. Anglici] locum suum quasi per unam leucam ab inimicis prope unum boscum et foderunt foveas et fossas circa eos et cooperuerunt eas de feno et herbagio; et post solis ortum paraverunt se ad bellum.

Then Charles of Blois came on to attack in three 'battles,' of which the first included many galleti, which means, I suppose, Welshmen - that is, Bretons bretonnants. It may be assumed that these attacked on foot.10 Anyhow they were immediately beaten, and then the other two French 'battles' came on. Knighton's words show that these were, as would naturally be the case, mounted men. He tells us how they

ferocitate animi duoti opprimere Anglise gentes moliti sunt; et equorum suorum validorum pedibus conculcare volentes capitose irruerant in eos, sed antris decepti obturatis, ut predictum est, ceciderunt quilibet super alinm in foveis abinvicem confusi.

Thus the host of Charles of Blois was defeated after a hard fight. Knighton does not tell us clearly all that we should wish to know, but it seems almost certain from his account that the English fought on foot. Otherwise the pits, suggested by Bannockburn and anticipating what Baker tella us of Crecy, would be unintelligible. No sane general would have marshalled men-at-arms mounted on restless and high-spirited chargers just behind a row of pits. An involuntary movement forward would have caused the same disaster as befell the Bretons. Moreover by this time the English habit of fighting on foot wes completely established. A more serious gap in the account is that we read nothing about the work of the archers. Yet, edmitting the deficiencies of the evidence, we cannot bat feel sure that Northampton in this obscure fight between Morlaix and Lanmeur sabstantially anticipated the

\footnotetext{
' Pp. 127, 128-9, Rolls Series. - Tbid. p. 127. - Chron, ii. 25, Rolls Series.

10 M. de la Borderie is quite Bare of this: 'La première [bataille] . . compose de ces tronpes trréguliàres de pied qu'on eppelait ribauds on galois ' (Hist. do Bretagne, iii. 167).
} 
array of Crecy. We have most of the essential point3-the defensive action, the flanking woods, the dismounted men-at-arms, the concealed pits, the great odds, the preliminary and futile attack of the enemg's foot, the rush of the heavy cavalry charge, and, after hard fighting, the decisive result. Even trivial analogies-the attack delayed till late in the day, ${ }^{11}$ and the inability of the scanty force of victors to do more than withdraw safely, complete the closeness of the anticipation of Crecy. And we must not forget that Northampton was in high command at Crecy, being one of the two leaders of the left 'battle' that flanked the array of the Black Prince. Consideration of these facts and inferences makes us realise that the historical comments of Geoffrey le Baker ${ }^{12}$ on the battle are something more than mere rhetoric.

Pugnatum est fortiter ex utraque parte, ita quod contigit illo certamine quod nee in bellis, neo de Helydonehiel nec de Cressi nec de Petters, audivimus contigisse.

The shrewdest judgment of the battle of Morlaix is that which thus makes it a link in the chain between Halidon Hill and Crecy and Poitiers. T. F. Toot.

\section{Tithing Lists from Essex, I329-1343.}

Manorial court-rolls contain constant references to various details of the tithing-8ystem. Very frequently, the record of a leet-court is headed by a list of the headmen (capitales plegii), by whose presentments, in answer to the 'Articles' propounded by the steward, the jurisdiction of the court was exercised. Less frequent are complete lists, showing the manner in which the tithing-men (decenarii) were grouped under these headmen. The following lists are found in the court-rolls of Chatham-Hall, one of the seven manors in the extensive parish of Great Waltham, Esser. In this, as in many other Essex manors, every member of the tithing had yearly to pay to the lord of the manor $1 d$. to make up the 'common fine' on the leet-day, and in these lists the sum for each tithing is noted. The tithings are six in number, each under the joint control of two headmen. The first list comes at the head of the court-leet roll for Tuesday in Easter week, 27 March, 1329 :

Chatham.-Visus franci plegii tenti ibidem die Martis in Septimana Paschae anno regni regis Edwardi tertii post conquestum tertio.

Cap. pleg. ( Robertus Levelif

xvd. $\left\{\begin{array}{cc}\text { Johannes } & \text { Startleg }\end{array}\right\}$ habent in eorum decena :-

"1 'Cires horem nonam' (Murimuth, p. 127), i.e. from 2 to 4 P.y., which would not lesve many hours of light on 80 Bept.

11 P. 76, ed. E. Maunde Thompson. 